\title{
Rotational Eustasy as Observed in Nature
}

\author{
Nils-Axel Mörner \\ Paleogeophysics \& Geodynamics, Stockholm, Sweden \\ Email: morner@pog.nu
}

How to cite this paper: Mörner, N.-A. (2019) Rotational Eustasy as Observed in Nature. International Journal of Geosciences, 10, 745-757. https://doi.org/10.4236/ijg.2019.107042

Received: May 26, 2019

Accepted: July 28, 2019

Published: July 31, 2019

Copyright (c) 2019 by author(s) and Scientific Research Publishing Inc. This work is licensed under the Creative Commons Attribution International License (CC BY 4.0).

http://creativecommons.org/licenses/by/4.0/

\begin{abstract}
Observational facts from the Maldives, Goa and Bangladesh in the Indian Ocean and from Fiji and New Caledonia in the Pacific record a high sea level in the 17th century, a low sea level in the 18th century, a high sea level in the early 19th century and a stable sea level in the last $50-70$ years. This cannot be understood in terms of glacial eustasy (or in terms of steric effects or tectonics), only in terms of rotational eustasy. The present paper gives a summary of the observational facts behind the formulation of the novel concept of rotational eustasy. It reveals a common trend of sea level changes, which is opposed to the sea level changes in the northern hemisphere, and the global climatic changes in general. Rotational eustasy offers a logical explanation.
\end{abstract}

\section{Keywords}

Sea Level Changes, Rotational Eustasy, Shore Morphology, Stratigraphy, Biological Criteria, Historical Data

\section{Introduction}

The theory of rotational eustasy emerged as a direct consequence of observational facts from numerous sites on a number of key areas in the Indian Ocean and the Pacific. The data obtained revealed that there was a missing factor in our understanding of the cause of sea level changes; the concepts of glacial eustasy and thermal water expansion were not able to explain the variations in sea level observed (nor were local tectonics). The additional factor needed was termed "rotational eustasy" and its physical understanding has been presented in a special paper of this journal [1].

A new theory stands and falls with the quality of the basic observational facts. Therefore, this paper presents a summary of available facts upon which the theory of rotational eustasy is based. Previously, each region was presented separately. It soon became obvious that there was a common trend in the sea level 
changes during the last 500 years within the Indian Ocean and the Pacific, and that this trend was very different from the records of the northern hemisphere and global climate in general. This paper highlights the facts (region for region) upon which the concept of rotational eustasy is based [1].

\section{Eustatic Test Areas in Europe}

The Stockholm area, the Kattegatt Sea and the Amsterdam region constitute excellent test areas for the regional eustatic component, because the absolute crustal component is known in detail (Stockholm going up by $4.9 \mathrm{~mm} / \mathrm{yr}$, the whole of the Kattegatt area being covered by absolute crustal movement documentation with the zero isobase fixed for the last 8000 years in the Great Belt area, the Amsterdam area subsiding at a rate of $0.4 \mathrm{~mm} / \mathrm{yr}$ ). The absolute eustatic component can be firmly fixed at $+1.05 \pm 0.15$ [2] [3] [4] [5] [6].

The regional eustatic component of the US East Coast seems to be in a similar order of magnitude [7] [8].

\section{The Maldives}

In 2000 we initiated the International Sea Level Project in the Maldives. After 6 expeditions, careful documentation of coastal morphology in different dynamic settings, stratigraphy, leveling and 57 C14-dates, a quite comprehensive picture was established of the sea level changes during the last 5000 years [9]-[16].

Figure 1 summarizes the main steps of the sea level changes during the last 500 years: $\mathrm{a}+50-60 \mathrm{~cm}$ high sea level in the 17 th century (Figure 2), a low sea level in the 18th century with submarine peat (Figure 3), and a $10-20 \mathrm{~cm}$ drop at around 1970 (Figure 4).

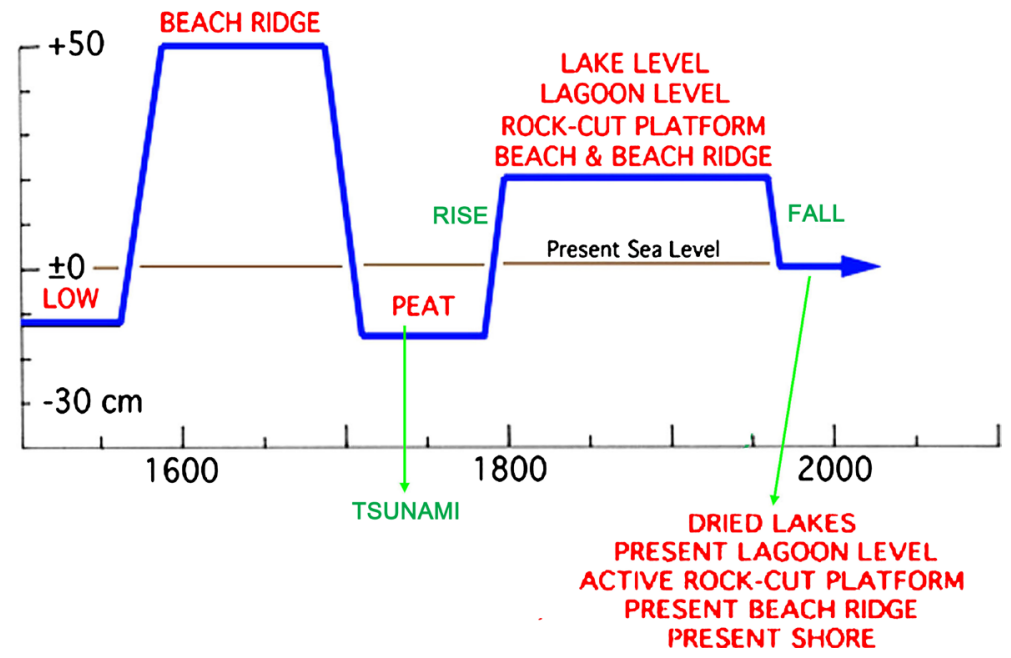

Figure 1. Summary of observer sea level changes in the Maldives during the last 500 years [10] [11] [13] [15]: a $+50-60 \mathrm{~cm}$ high sea level in the 17th century (i.e. during the Maunder Minimum cold period), a low level (probably well below $-15 \mathrm{~cm}$ ) in the 18th century (i.e. during the 18th century warm period), a very rapid rise to a $+10-20 \mathrm{~cm}$ level in about 1790 (i.e. at the onset of the Dalton Minimum cold period), a sudden fall at about 1970, and stable conditions during the last 50 years. 

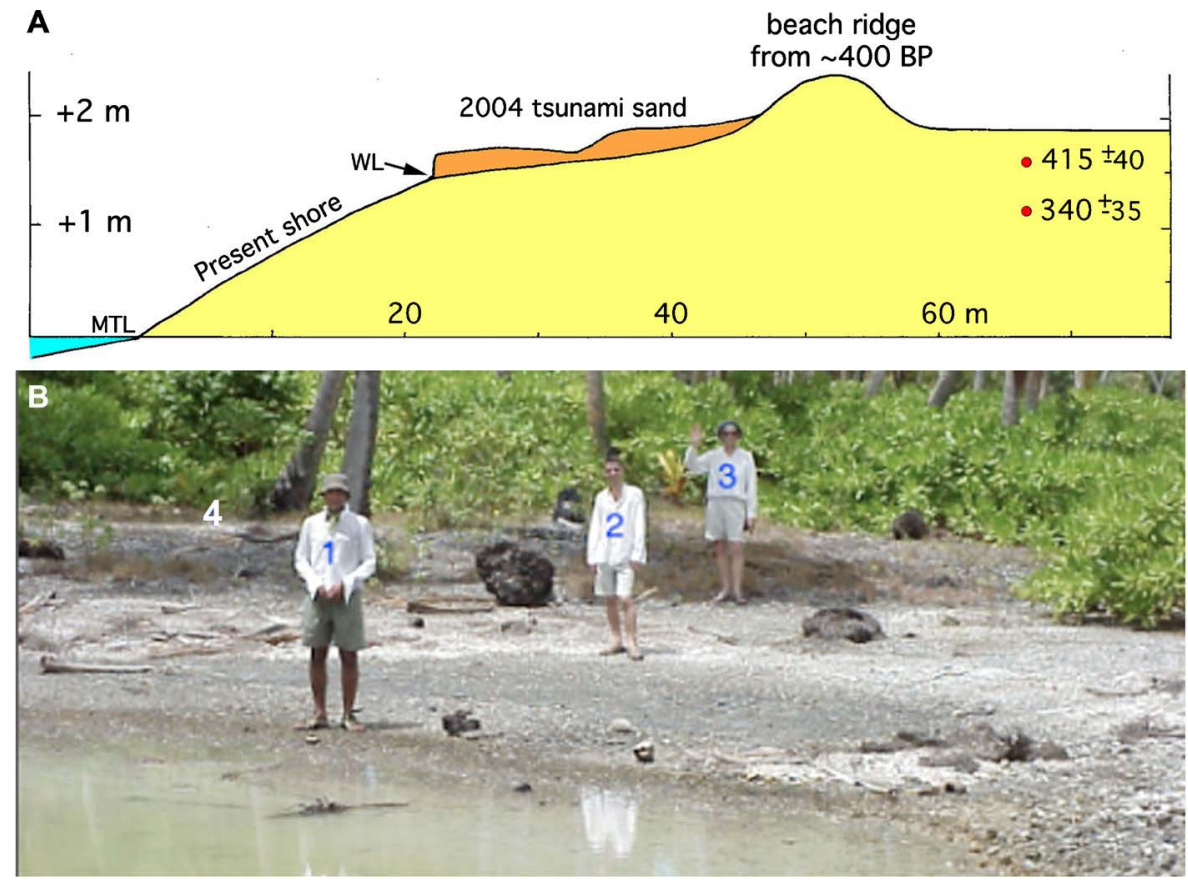

Figure 2. The +50 - $60 \mathrm{~cm}$ level in the 17th century: (A) beach ridge dated at about $400 \mathrm{BP}$. (B) a sequence of lagoonal shore levels: (4) at $+60 \mathrm{~cm}$ from about $400 \mathrm{BP}$, (3) a $+20-30 \mathrm{~cm}$ from the pre-1970 shore level, and (2) and (1) from the present HTL and MTL [7] [11].

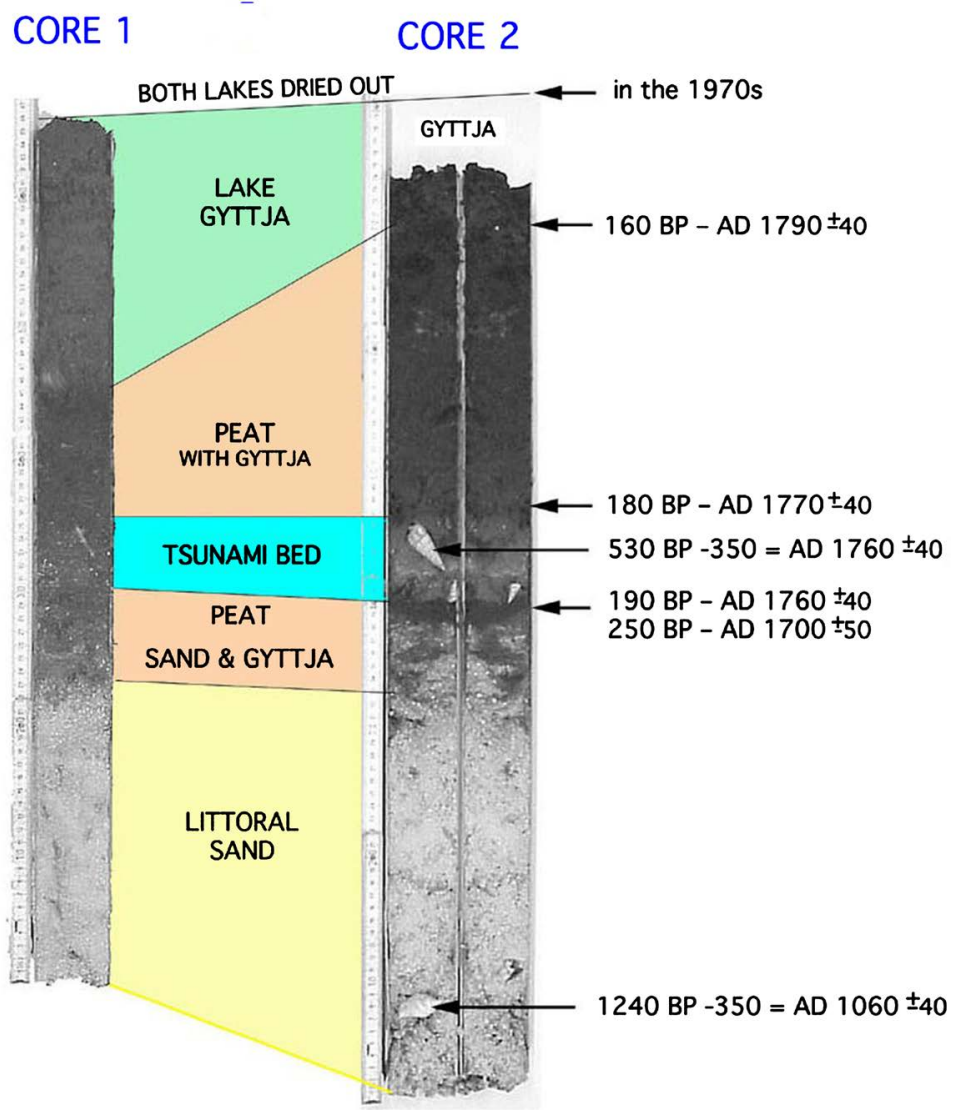

Figure 3. Submarine peat from the Guidhoo Atoll with Core 2 from the northern side and Core 1 from the southern side of the island, recording a low sea level in the 18th century (peat including a tsunami bed [10] [12] [15]), a rise in sea level at about 1790 (the change from peat to lake gyttja) and a fall in sea level at about 1970 (the drying up off both lakes). 


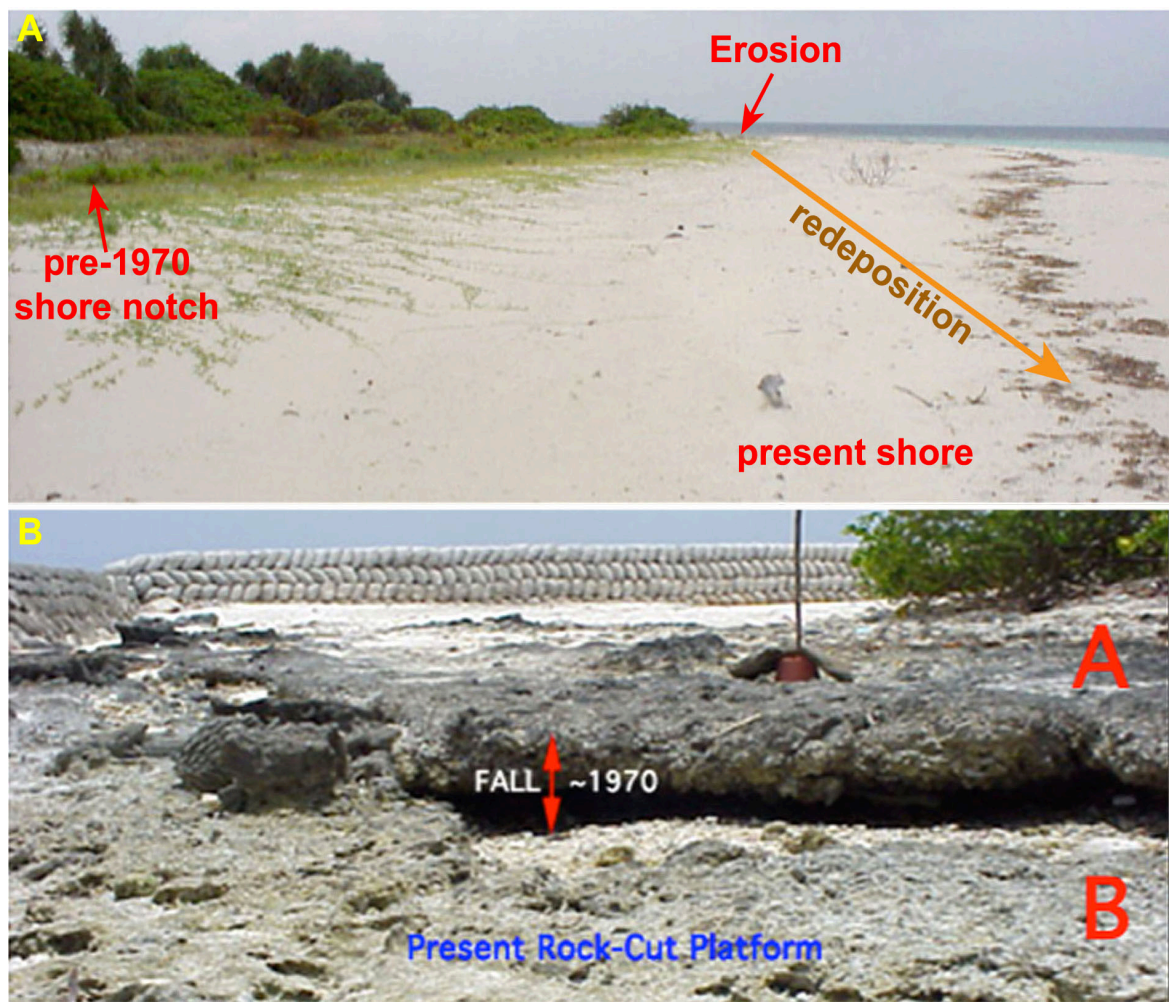

Figure 4. The $20 \mathrm{~cm}$ sea level fall at about 1970 [11] [13] [15] [16]. (A) the lowering induces strong erosion with the redeposition of eroded sand at a lower sea level. The old shore notch is abandoned, and the old shore is in the process of becoming over-grown. (B) a double rock-cut platform. The old platform (A) is left and weathered (in a map from 1922 it was covered by water), and the new platform is fresh and under-going present-day erosion. The notch between the two platforms is weathered and without signs of erosion indicating stable sea level conditions today.

\section{Goa, India}

In Goa, it was possible to establish a very comprehensive record of sea level changes during the last 500 years [15] by applying a combination of shore morphology, stratigraphy, biological index levels, archaeological buildings, old harbours, the scenery in an old painting, historical notes and tide gauge records. The database is summarized in Figure 5.

There is a clear $+60 \mathrm{~cm}$ high sea level dated at $1615 \pm 12 \mathrm{cal}$. yrs BP (Figure 6), a submarine building at about $-1 \mathrm{~m}$ dated at 1700-1750 $\mathrm{AD}$ (Figure 7), a 20 $\mathrm{cm}$ drop in sea level at about 1960 (Figure 8), and a stable sea level over the last 60 (Figure 5).

\section{Bangladesh}

The Bangladesh sea level record is summarized in Figure 9 [16] [17] [18]. It shows the occurrence of a clear low sea level stage in the late 18th to 17th century [18] and a drop in sea level of about $10-20 \mathrm{~cm}$ at about 1960 [17]. There seems also to be stratigraphical records of the 1733 tsunami during the formation of the low sea level deposits [12]. 


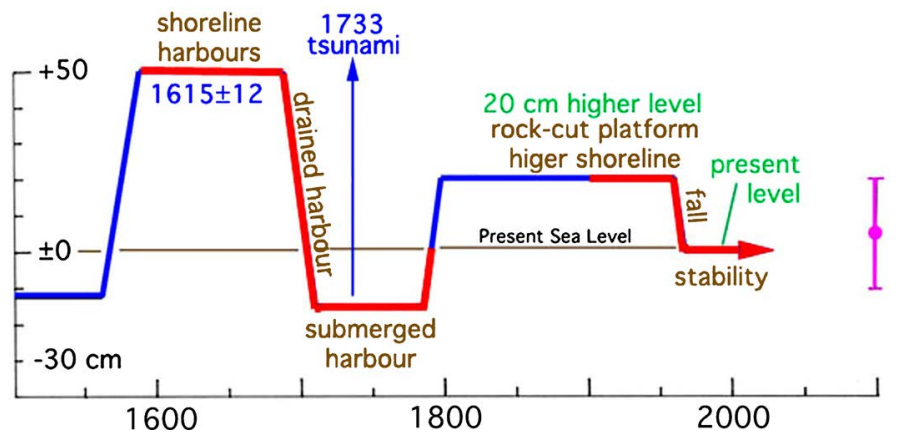

Figure 5. Sea level changes in Goa, India, during the last 500 years [15] [16].

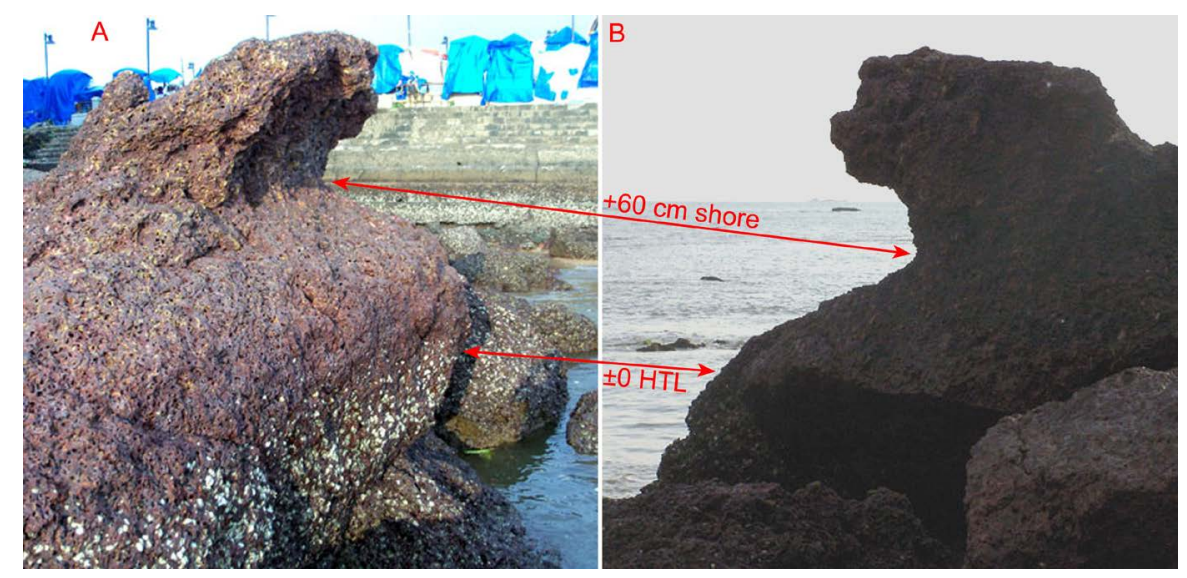

Figure 6. A distinct undercut notch located $60 \mathrm{~cm}$ above the present upper limit of living barnacles marking the position of the present HTL [15] [16]. The $+60 \mathrm{~cm}$ sea level is dated at the 17 th century.

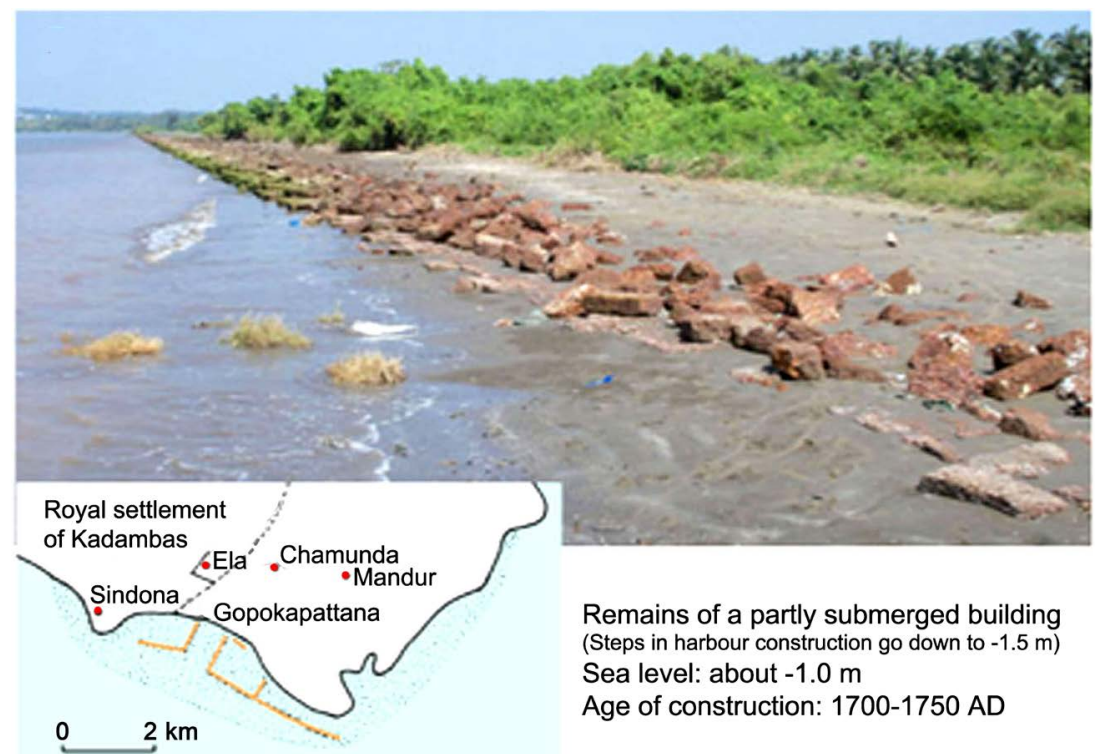

Figure 7. Remains of a partly submerged building and harbour construction dating at 1700-1750 when sea level was $1.0-1.5$ m lower than today [11] [13]. In an old painting of the city of Old Goa [7] [15] [16], there are two harbours; an old and dried-up one with abandoned ships (obviously from the high sea level during the 17th century) and an active harbour at the riverside with ships in operation (obviously from the low sea level in the 18th century). 


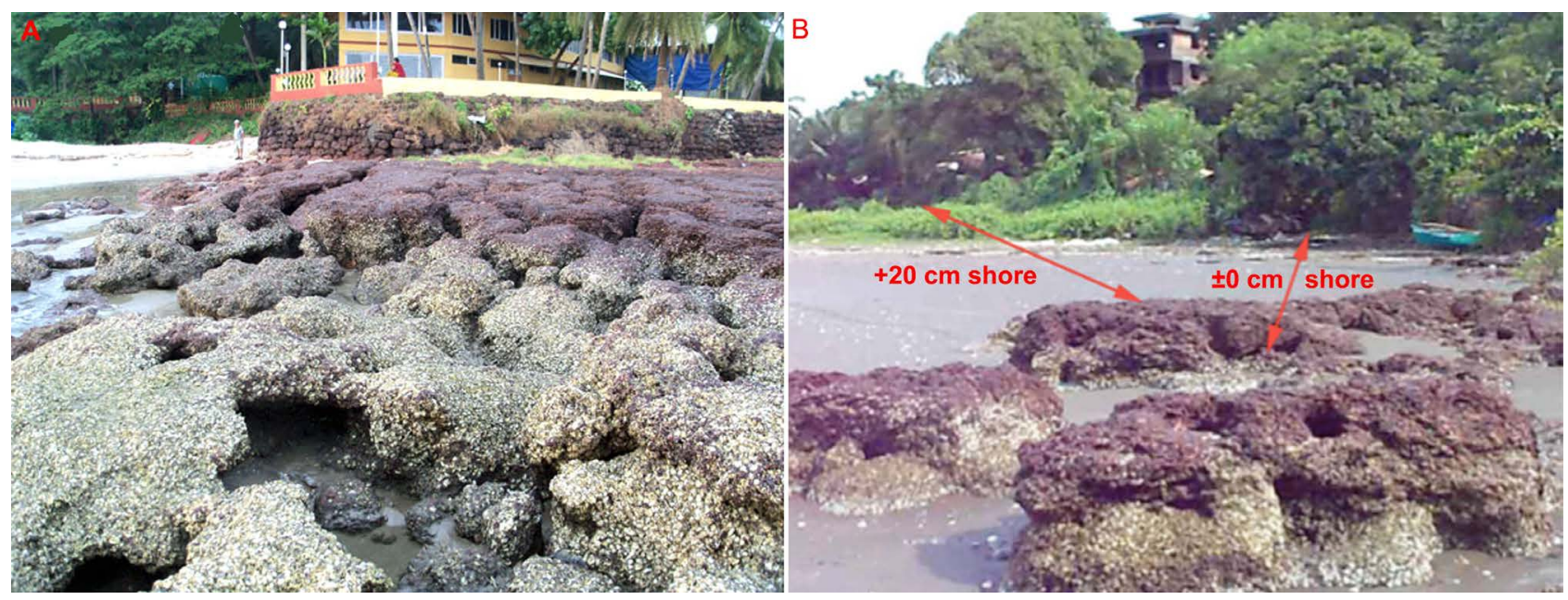

Figure 8. The pre-1960 and post-1960 sea levels with a $20 \mathrm{~cm}$ difference in elevation [15] [16]. A: double rock-cut levels; the upper abandoned and weathered at $+20 \mathrm{~cm}$, and the lower covered by living barnacles at $\pm 0 \mathrm{~cm}$ HTL. B: similar double levels but with the upper level connected with the foot of the dead bedrock cliff and the lower connected to a segment of active erosion along the old rock cliff.

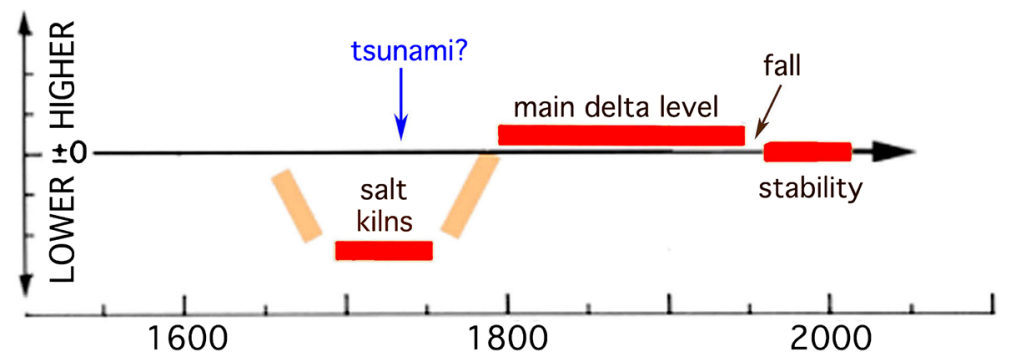

Figure 9. Sea level changes in Bangladesh during the last 500 years [15] [16] [17] [18].

\section{The Fiji Islands}

In the Yasawa Islands of the Fiji Islands, we undertook extensive shore morphological analyses and dating [16] [19] [20] giving a detailed record of the sea level changes during the last 500 years (Figure 10).

There is a clear $+70 \mathrm{~cm}$ high sea level record dated at the late 16th to late 17th century (Figure 11), a low sea level in the 18th century reaching $-100-70 \mathrm{~cm}$ (Figure 12), a $+30 \mathrm{~cm}$ in the early 19th century (Figure 13), a stable sea level over the last 150 (Figure 13) years with a $10-20 \mathrm{~cm}$ lowering in the late 20th century and perfectly stable sea level conditions for the last 20 - 60 years forcing coral growth into microatolls (Figure 14).

\section{Ouvéa Island in New Caledonia}

On the Ouvéa Island there are excellent records of the $+70 \mathrm{~cm}$ sea level of the 17th century (Figure 15, with additional illustrations in [1]. There is also morphological evidence of the absence of a present sea level rise [21]. Figure 16 shows the $+70 \mathrm{~cm}$ shore, the sub-recent $+20 \mathrm{~cm}$ level now abandoned and overgrown, and the present stable sea level. A recent $20 \mathrm{~cm}$ fall in sea level (in the 1950s) is well documented in Figure 17. 


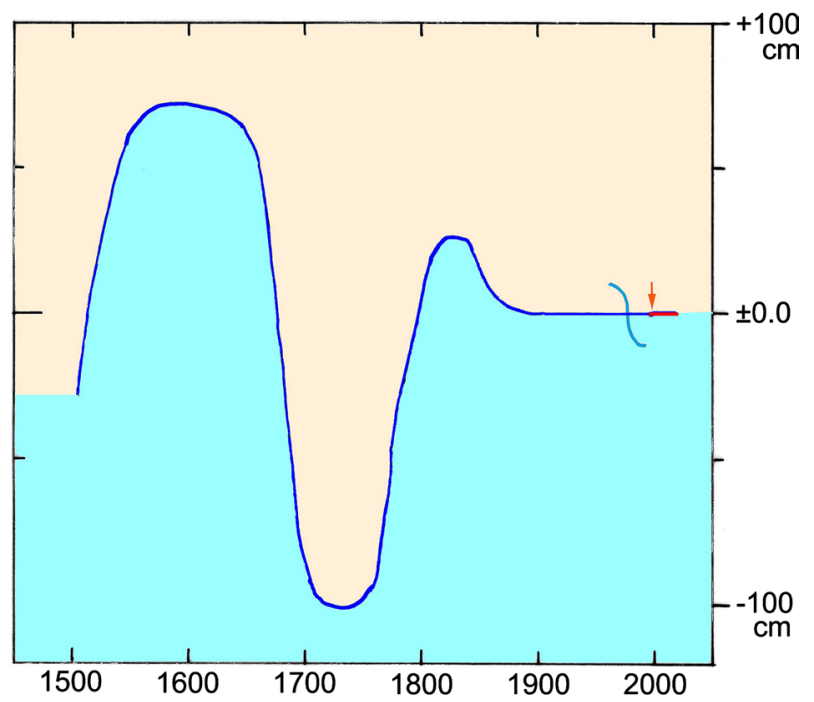

Figure 10. Summary of observed, documented and dated sea level changes in the Yasawa Island of the Fiji Islands [19] [20].

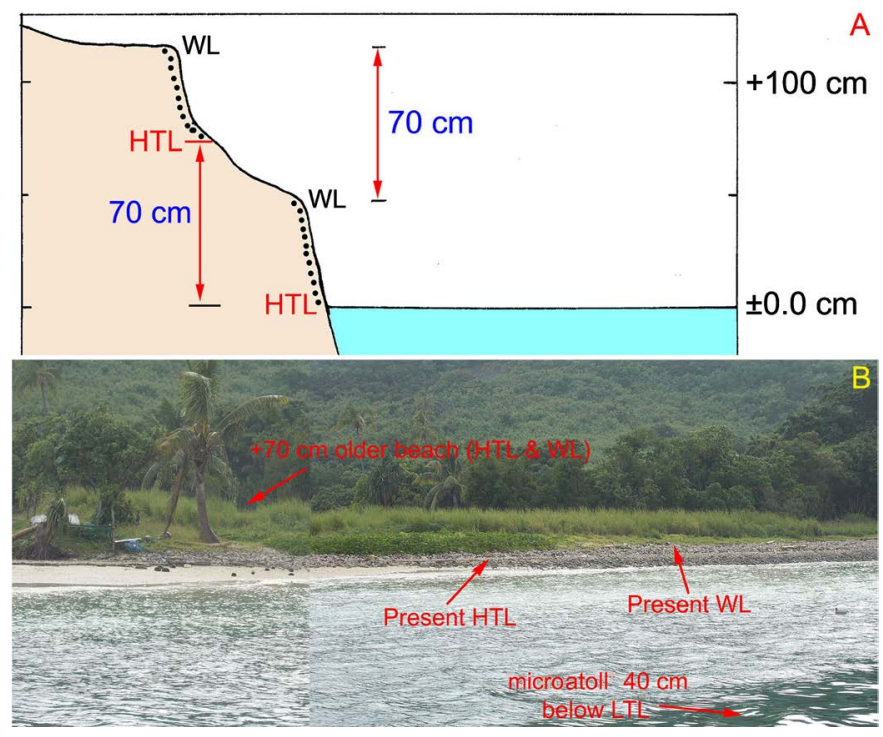

Figure 11. The $+70 \mathrm{~cm}$ has a high-tide level (HTL) and washing limit (WL) lying exactly $70 \mathrm{~cm}$ above the present HTL and WL. A coral from the $+70 \mathrm{~cm}$ beach was dated at 1601 $\pm 143 \mathrm{BP}[19]$.
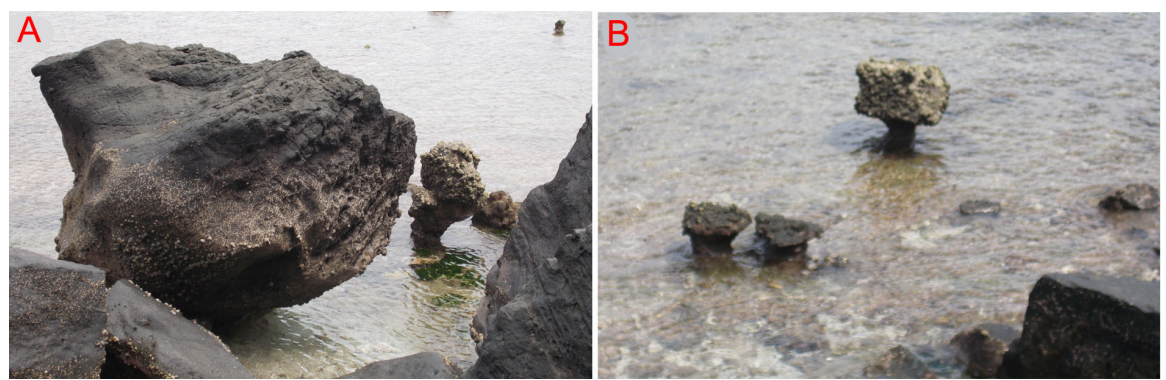

Figure 12. The 18th century is represented by a low sea level generating a HTL rock-cut platform with under-cut notches and coral erosion at present LTL; i.e. at a level of about $-70-100 \mathrm{~cm} \mathrm{[19].}$ 

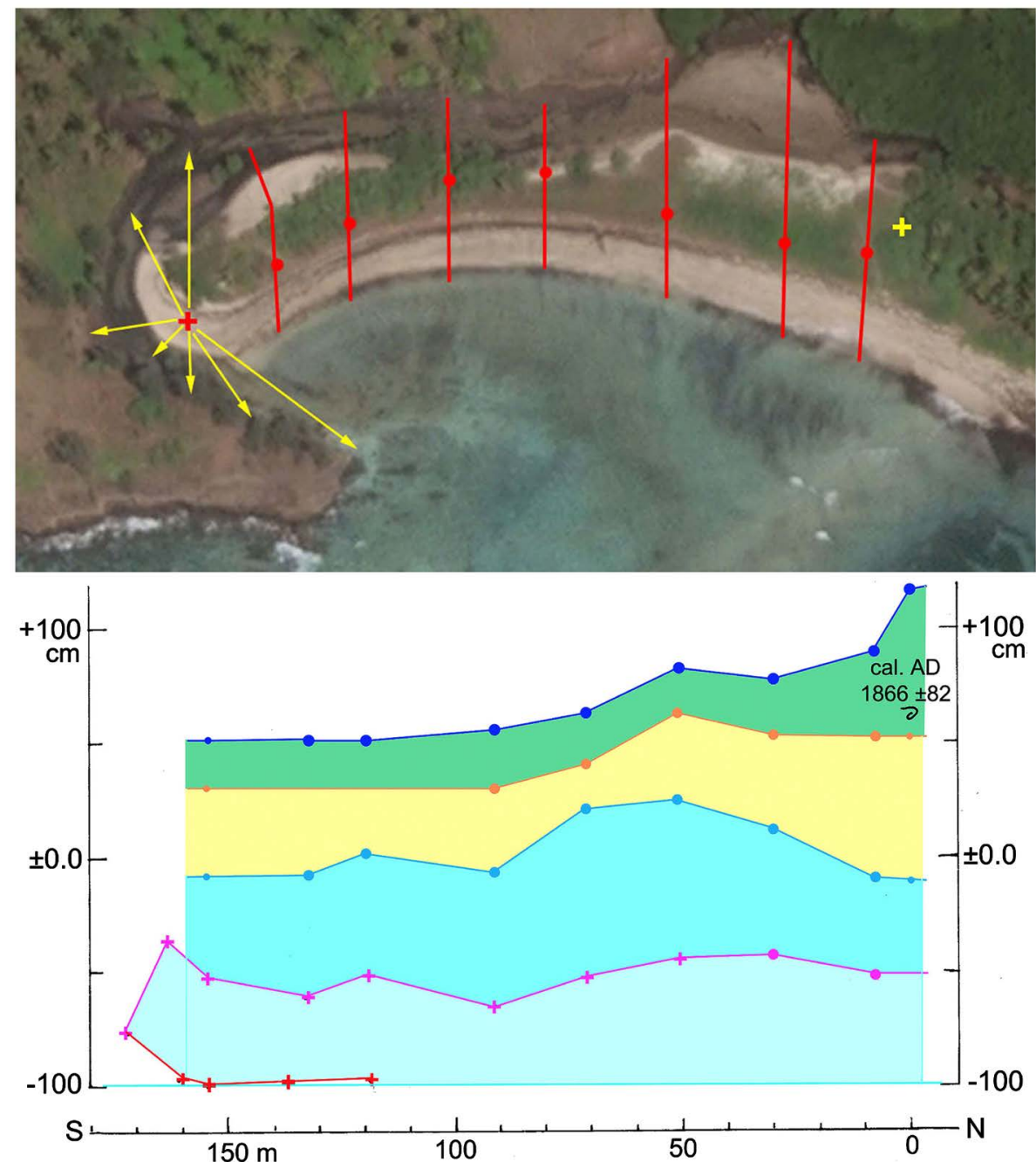

Figure 13. A $160 \mathrm{~m}$ long coastal barrier was built out by about $1 \mathrm{~m}$ per year (C14-date at yellow cross). The crest (green) was higher in the beginning and then fairly flat (indicating no present rise in sea level). Yellow $=$ WL, blue $=$ HTL, purple $=$ notch on the lagoonal side (MTL), orange = HTL during the 18th century low sea level [19].
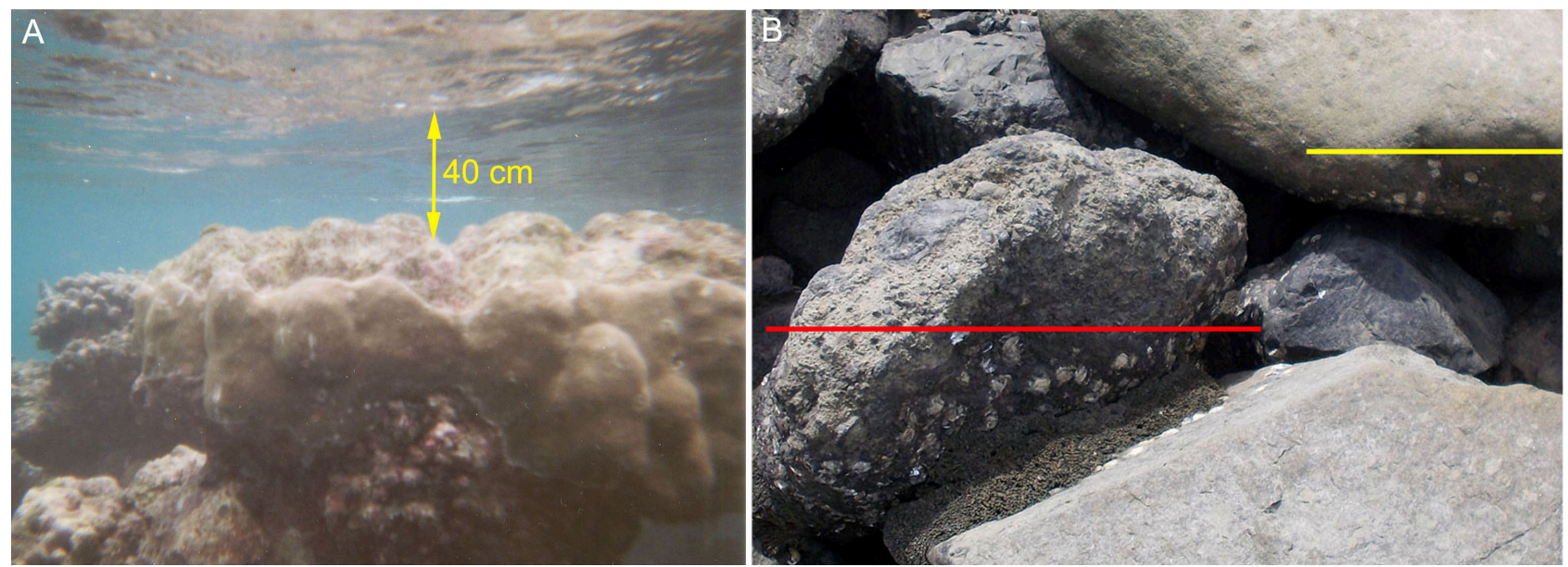

Figure 14. In the late 20th century, sea level fell killing many corals (the centre in image A) and forcing corals to grow as microatolls (A), which indicates quite stable sea level conditions for the last 20 - 60 years. The drop in sea level is also seen in the difference between the upper limit of dead (yellow) and living (red) patella shells and barnacles (B) [16] [19]. 

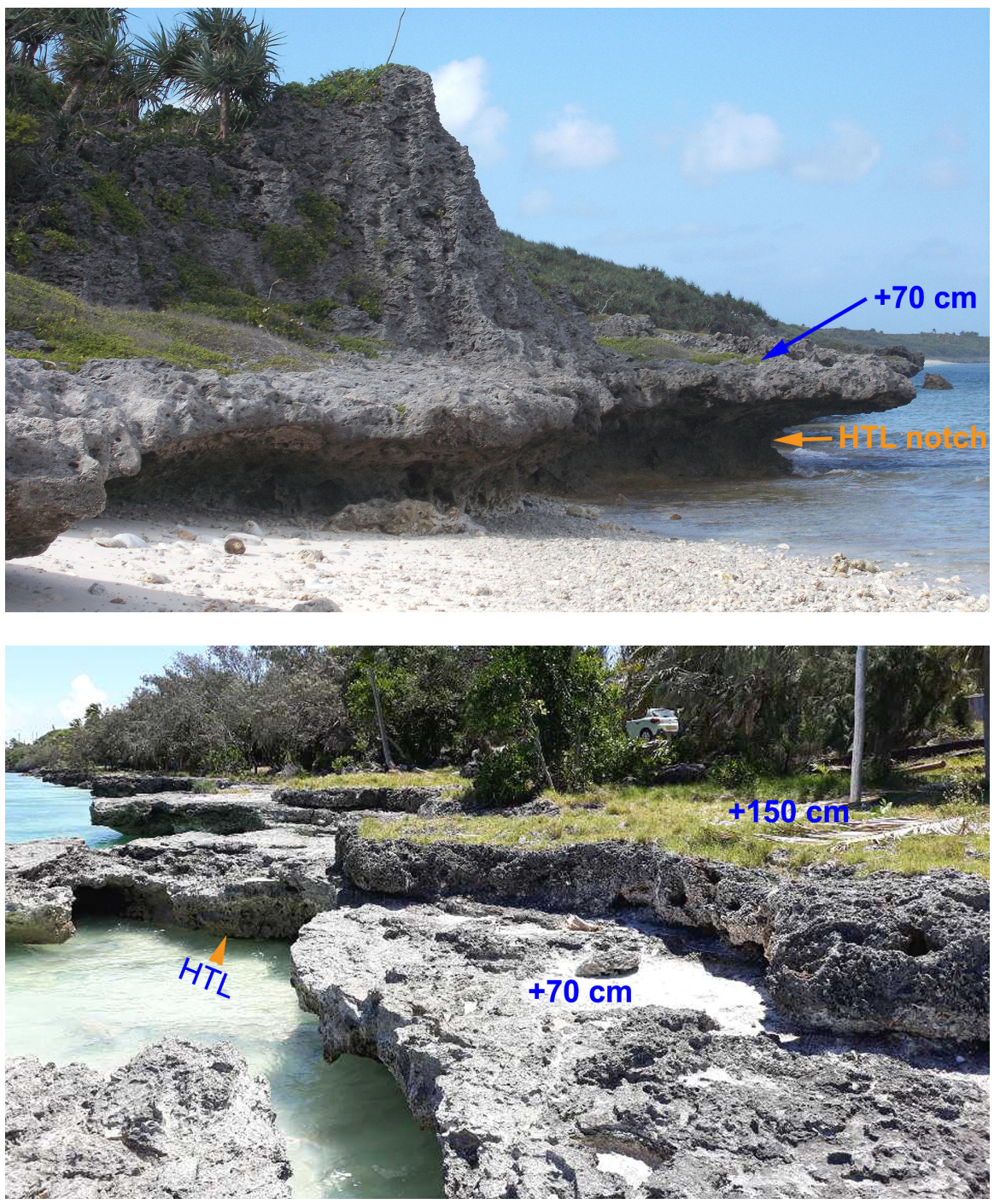

Figure 15. Ouvéa Island: the $+70 \mathrm{~cm}$ sea level of the 17 th century is a very pronounced shore level.

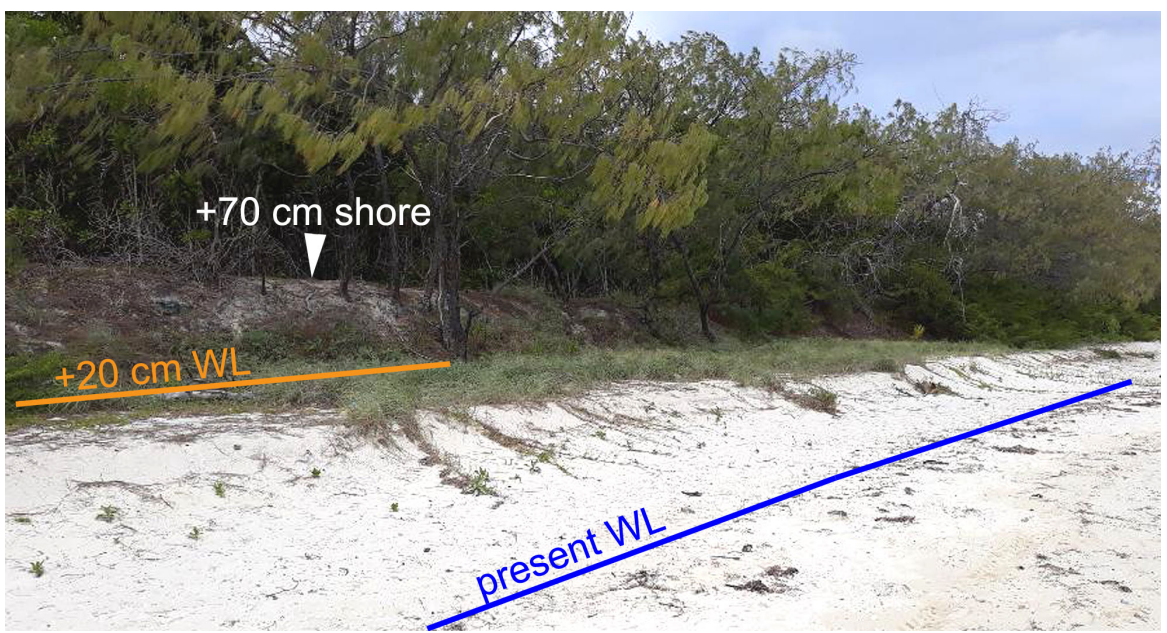

Figure 16. The $+70 \mathrm{~cm},+20 \mathrm{~cm}$ and present shores in a sandy environment of northwest Ouvéa Island. 

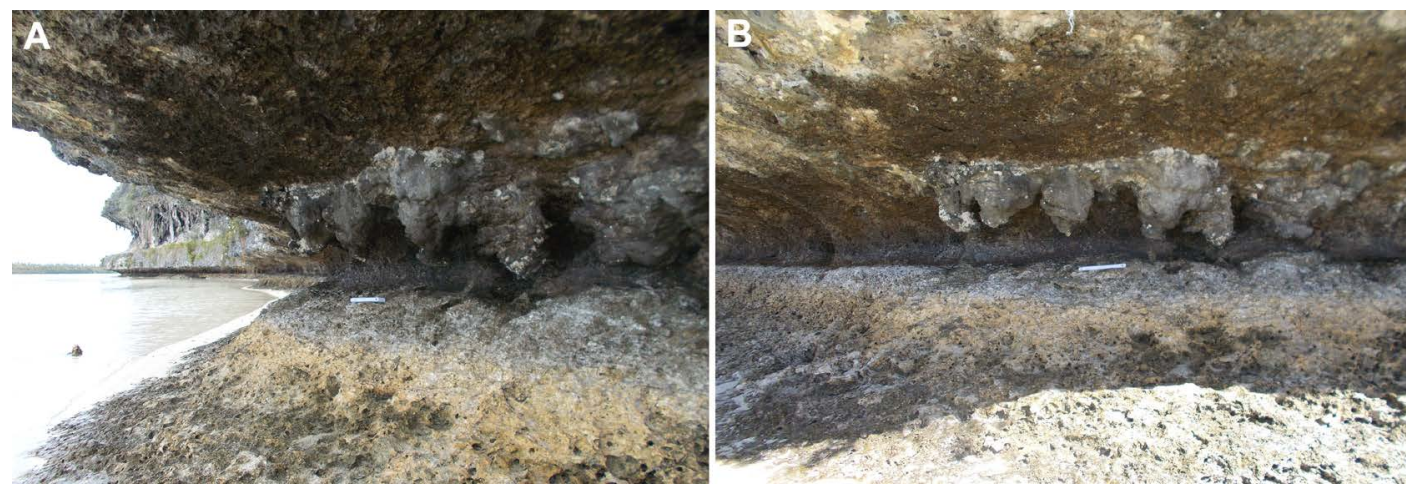

Figure 17. The $+20 \mathrm{~cm}$ HTL under-cut notch of the 1800-1950 period, and the present HTL some $20-30 \mathrm{~cm}$ below. Stalactites in the roof of the under-cut notch give evidence of subaerial environment.

\section{Some Other Sites}

The absence of a present-day rise in sea level is documented from many other sites in the equatorial region of the Indian Ocean and the Pacific. This is the case with the Minicoy Island [7] [15], St. Paul Island [15] and Qatar [22] in the Indian Ocean, and Tuvalu [11] [23], Vanuatu [11], Kiribati [24] [25] and Samoa [26] in the Pacific.

\section{Conclusions}

The observational facts highlighted above (see also [16]) document the following sequence of events recorded by multiple records in the Indian Ocean and the Pacific:

1) A $+60-70 \mathrm{~cm}$ high sea level in the late 16th to 17 th century, well recorded and dated in the Maldives, Goa, Fiji and New Caledonia.

2) A low sea level (well below the present one) in the 18th century, well recorded and dated in the Maldives, Goa, Bangladesh and Fiji.

3) A $+30 \mathrm{~cm}$ high sea level in the early 19th century, well recorded in the Maldives, Goa and Fiji (also seen in Ouvéa Island).

4) A stable sea level $10-20 \mathrm{~cm}$ above the present one in the late 19th to early 20th centuries, well recorded in the Maldives, Goa, Bangladesh, Fiji and New Caledonia.

5) A 10 - $20 \mathrm{~cm}$ sea level lowering in 1950-1970, well recorded in the Maldives, Goa, Bangladesh, Fiji and New Caledonia

6) Stable sea level conditions in the last 20 - 60 years, as documented in the Maldives, Goa, Bangladesh, Fiji, New Caledonia and a number of other sites (e.g. Minicoy, St. Paul Island and Qatar in the Indian Ocean, and Tuvalu, Vanuatu, Kiribati and Samoa in the Pacific).

The sea level records are so similar [1] [7] [13] [15] [19] [21] that they can be combined into a common sea level curve of the last 500 years (Figure 18(A)) valid for the equatorial regions of the Indian Ocean and the Pacific. This curve is totally different than the one obtained for the eustatic test areas of northwestern Europe (Figure 18(B)). This can only be understood in terms of rotational eustasy 


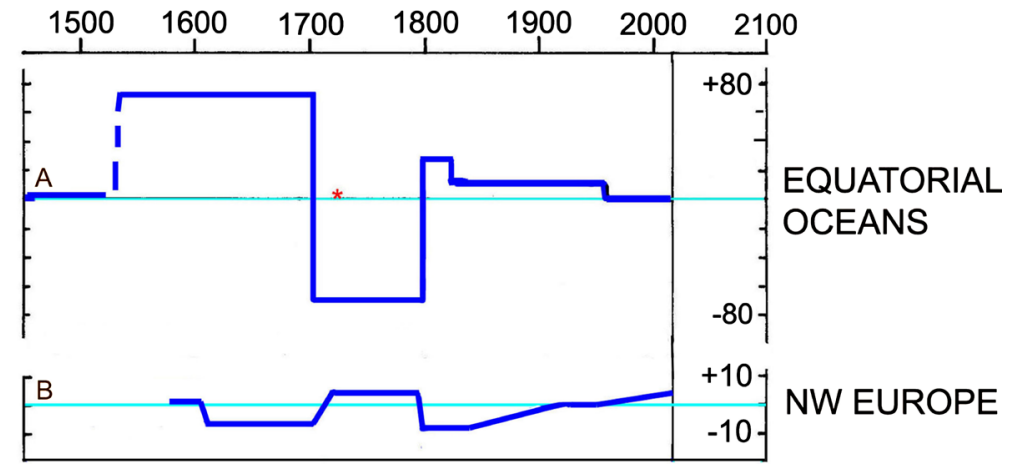

Figure 18. (A) the combined eustatic curve of the equatorial regions (below $30^{\circ}$ N.Lat.) for the last 500 years, and (B) the eustatic curve from the NW European eustatic test areas of the Baltic, the Kattegatt and the North Sea. Whilst curve B follows the general climatic changes quite well and hence seems to be dominated by glacial eustasy, curve A is in opposed mode and have oscillations of much higher amplitudes, indicating that it is dominated by other forcing functions, viz. rotational eustasy [1].

[19] [20] [21] calling for a separate explanation in terms of physics as presented and further discussed in a separate paper [1].

\section{Acknowledgements}

I thank all colleagues actively involved in the field studies and all local persons so generously assisting us in the field. I am indebted to Pamela Matlack-Klein for skilful linguistic review of the paper.

\section{Conflicts of Interest}

The author declares no conflicts of interest regarding the publication of this paper.

\section{References}

[1] Mörner, N.-A. (2019) Rotational Eustasy as Understood in Physics. International Journal of Geosciences, 10, 709-723. https://doi.org/10.4236/ijg.2019.106040

[2] Mörner, N.-A. (1969) The Late Quaternary History of the Kattegatt Sea and the Swedish West Coast: Deglaciation, Shorelevel Displacement, Chronology, Isostasy and Eustasy. Sveriges Geologiska Undersökning, C-640, 1-487.

[3] Mörner, N.-A. (1973) Eustatic Changes during the Last 300 Years. Palaeogeography, Palaeoclimatology, Palaeoecology, 13, 1-14. https://doi.org/10.1016/0031-0182(73)90046-1

[4] Mörner, N.-A. (2014) Deriving the Eustatic Sea Level Component in the Kattegatt Sea. Global Perspectives on Geography, 2, 16-21.

[5] Hansen, J.M. (2015) Sea-Level Effects of NAO and AMO: Synchronization and Amplitude Locking by the Lunar Nodal Oscillation in the North Sea and Baltic Embayment. In: Mörner, N.-A., Ed., Planetary Influence on the Sun and the Earth, and a Modern Book-Burning, Nova Science Publishers, New York, 51-70.

[6] Baart, F., Rongen, G., Hijma, M., Kooi, H., de Winter, R. and Nicolai, R. (2018) Zeespiegelmonitor 2018. Deltares, Utrecht.

[7] Mörner, N.-A. (2016) Sea Level Changes as Observed in Nature. In: Easterbrook, 
D.J., Ed., Evidence-Based Climate Science, Second Edition, Elsevier, Amsterdam, 215-229. https://doi.org/10.1016/B978-0-12-804588-6.00012-4

[8] Wysmuller, T. (2018) The Fall of IPCC’s Sea Level Rise. In: Mörner, N.-A., Matlack-Klein, P. and da Assuncao Araujo, M., Eds., Basic Science: How Processes in the Sun, Atmosphere and Ocean Affect Weather and Climate, The Porto Climate Conference 2018, Porto University, Porto, Portugal, 61-62.

https://www.researchgate.net/publication/326882331

[9] Mörner, N.-A., Tooley, M. and Possnert, G. (2004) New Perspectives for the Future of the Maldives. Global Planetary Change, 40, 177-182. https://doi.org/10.1016/S0921-8181(03)00108-5

[10] Mörner, N.-A. (2007) Sea Level Changes and Tsunamis, Environmental Stress and Migration Overseas. The Case of the Maldives and Sri Lanka. Internationales Asienforum, 38, 353-374.

[11] Mörner, N.-A. (2007) The Greatest Lie Ever Told. P \& G Print, Stockholm, 20 p (2nd Edition in 2009, 3rd Edition in 2010).

[12] Mörner, N.-A., Laborel, J. and Dawson, S. (2008) Submarine "Sandstorms" and Tsunami Events in the Indian Ocean. Journal of Coastal Research, 24, 1608-1611.

[13] Mörner, N.-A. (2011) The Maldives: A Measure of Sea Level Changes and Sea Level Ethics. In: Easterbrook, D.J., Ed., Evidence-Based Climate Science, Elsevier, Amsterdam, 197-209. https://doi.org/10.1016/B978-0-12-385956-3.10007-5

[14] Mörner, N.-A. (2017) The Reef Woman of the Maldives. Archaeological Discovery, 5, 238-244. https://doi.org/10.4236/ad.2017.54014

[15] Mörner, N.-A. (2017) Coastal Morphology and Sea-Level Changes in Goa, India, during the Last 500 Years. Journal of Coastal Research, 33, 421-434. https://doi.org/10.2112/JCOASTRES-D-16A-00015.1

[16] Mörner, N.-A. (2019) Biology and Shore Morphology: Keys to Proper Reconstruction of Sea Level Changes. Journal of Marine Biology and Aquascape, 1-020, 1-5. http://dx.doi.org/\%2010.31579/26415143/JMBA.2019\%20/020

[17] Mörner, N.-A. (2010) Sea Level Changes in Bangladesh: New Observational Facts. Energy \& Environment, 21, 249-263. https://doi.org/10.1260/0958-305X.21.3.235

[18] Hanebuth, T.J.J., Kudrass, H.R., Linstädter, J., Islam, B. and Zander, A.M. (2013) Rapid Coastal Subsidence in the Central Ganges-Brahmaputra Delta (Bangladesh) Since the 17th Century Deduced from Submerged Salt-Producing Kilns. Geology, 41, 987-990. https://doi.org/10.1130/G34646.1

[19] Mörner, N.-A. and Matlack-Klein, P. (2017) New Records of Sea Level Changes in the Fiji Islands. Oceanography \& Fishery, Open Access Journal, 5, Article ID: 555666. https://doi.org/10.19080/OFOAJ.2017.05.555666

[20] Mörner, N.-A. (2017) Our Oceans-Our Future: New Evidence-Basted Sea Level Records from the Fiji Islands for the Last 500 Years Indicating Rotational Eustasy and Absence of a Present Rise in Sea Level. International Journal of Earth \& Environmental Sciences, 2, 137. https://doi.org/10.15344/2456-351X/2017/137

[21] Mörner, N.-A. (2018) Absolute Evidence of the Absence of an on-Going Sea Level Rise on Ouvéa Island of New Caledonia. International Journal of Geoinformatics and Geological Science, 5, 30-33. https://doi.org/10.14445/23939206/IJGGS-V5I3P104

[22] Mörner, N.-A. (2015) The Flooding of Ur in Mesopotamia in New Perspectives. Archaeological Discovery, 3, 26-31. https://doi.org/10.4236/ad.2015.31003

[23] Parker, A. (2018) Tuvalu Sea Level Rise, Land Change, Mismanagement and Over- 
population. New Concepts in Global Tectonics Journal, 6, 107-123.

[24] Mörner, N.-A. (2015) Open Letter to President Anote Tong of Kiribati. ResearchGate.

[25] Parker, A. (2016) Analysis of the Sea Levels in Kiribati a Rising Sea of Misrepresentation Sinks Kiribati. Nonlinear Engineering, 5, 37-43.

https://doi.org/10.1515/nleng-2015-0031

[26] Mörner, N.-A., Parker, A. and Matlack-Klein, P. (2018) Deformations of Land, Sea and Gravity Levels by the 2009 Samoa Earthquake. International Journal of Geosciences, 9, 579-592. https://doi.org/10.4236/ijg.2018.910034 